\title{
Perilaku Merokok Remaja Laki-laki Siswa SMP Swasta di Depok
}

\section{Smoking Behavior among Male Adolescent on Private Junior High Schools in Depok}

\author{
Nurul Huriah Astuti ${ }^{(1),(2)}$, Sandra Barinda ${ }^{(2)}$, Tegar Septyan Hidayat ${ }^{(2)}$, \\ Fika Minata Wathan ${ }^{(2)}$, Yulherina ${ }^{(2)}$, Duta Liana ${ }^{(2)}$ \\ (1) Fakultas Ilmu-Ilmu Kesehatan Universitas Muhammadiyah Prof. DR. HAMKA \\ (2) Program Doktor Ilmu Kesehatan Masyarakat Fakultas Kesehatan Masyarakat Universitas Indonesia
}

Korespondensi Penulis: Nurul Huriah Astuti, Fakultas Ilmu-Ilmu Kesehatan Universitas Muhammadiyah Prof. DR. HAMKA, Email: nurul_taqia@uhamka.ac.id

\begin{abstract}
ABSTRAK
Analisis data Riskesdas 2007, 2013, 2018 mendapatkan bahwa proporsi masyarakat yang merokok setiap hari di Indonesia berturut-turut adalah 23,7\%, 24,3\%, dan 28,8\% dari total jumlah penduduk. Meskipun faktor-faktor risiko perilaku merokok di kalangan remaja di Indonesia sudah banyak diteliti, namun pengetahuan secara mendalam mengenai peranan niat, norma subyektif, dan lingkungan sosial masih belum banyak diteliti. Penelitian ini bertujuan untuk mengetahui informasi mendalam tentang gambaran niat, norma subyektif, dan lingkungan sosial yang mendukung dan menghambat perilaku merokok di kalangan remaja laki-laki siswa SMP Swasta X di Kota Depok. Penelitian ini merupakan penelitian kualitatif dengan rancangan Rapid Assesment Procedure (RAP). Informan yang terlibat dalam penelitian ini ada 10 orang dan 1 orang informan kunci yang diwawancarai dengan menggunakan teknik Wawancara Mendalam (WM). Triangulasi dilakukan dengan menggunakan triangulasi sumber. Hasil penelitian ini menunjukkan faktor norma subyektif adalah faktor yang paling berpengaruh dalam membentuk perilaku merokok remaja pria tersebut. Sedangkan iklan rokok adalah faktor yang paling sedikit mempengaruhi remaja merokok. Norma subyektif yang terbentuk dari teman sebaya adalah merokok merupakan identitas remaja ketika bercengkrama dengan teman bermainnya. Bercengkrama tanpa rokok adalah hal yang tabu buat remaja, sehingga dorongan merokok lebih utama berasal dari teman sebaya. Di sisi lain, edukasi yang membangun keterampilan hidup (life skill) remaja belum didapatkan oleh informan.
\end{abstract}

Kata kunci: remaja perokok, norma subyektif, penelitian kualitatif

ABSTRACT

Analysis of Riskesdas 2007, 2013, 2018 data shows that the ratio of people who smoke every day in Indonesia combined is $23.7 \%, 24.3 \%$, and $28.8 \%$ of the total population. Although risk factors for smoking behavior among adolescents in Indonesia have been widely investigated in various surveys, in-depth knowledge of the role of intention, subjective norms, and social environment is still not widely studied. This study aims to found out in-depth information about the description of the factors that support and inhibit the occurrence of smoking behavior among teenage boys in the Middle School Masters in Depok City. This research was a qualitative study with a Rapid Assessment Procedure (RAP). The informants involved in this study were 10 people and 1 key informant interviewed using the Deep Interview technique. Triangulation is done using source triangulation. The results of this study indicated that subjective norm factors were the most influential factors in shaping the smoking behavior of young men. While cigarette advertising was the factor that least affects teenagers smoking. Subjective norms that were formed from peers was smoking was the identity of adolescents when chatting with their playmates. Chatting without cigarettes was a taboo thing for teenagers, so the urge to smoke was primarily from peers. On the other hand, education that builds life skills (life skills) of adolescents has not been obtained by informants yet.

Keywords: smoking youth, subjective norms, qualitative research 


\section{PENDAHULUAN}

Hasil Riskesdas 2007，2013， 2018 mendapatkan bahwa proporsi masyarakat yang merokok setiap hari di Indonesia berturut-turut adalah $23,7 \%, 24,3 \%$, dan $28,8 \%$ dari total jumlah penduduk (Kemenkes RI, 2013; Kementerian Kesehatan RI, 2018). Pada tahun 2007 terdapat 53,4 juta penduduk Indonesia merokok setiap hari, meningkat menjadi 60,4 juta pada tahun 2013, dan 76,32 juta jiwa pada tahun 2018 , penduduk Indonesia pada tahun 2018 adalah 265 juta jiwa. Data kematian juga menyebutkan sedikitnya di Indonesia, ada 25.000 kematian terjadi karena asap rokok orang lain atau perokok pasif, yaitu mereka yang tidak merokok tetapi terpapar asap rokok orang lain (Kemenkes RI, 2013). Selain itu, diperkirakan $85 \%$ rumah tangga di Indonesia terpapar asap rokok (Kemenkes RI, 2013).

Efek merokok pada kesehatan sudah diketahui sejak lama. Penelitian menyatakan bahwa mereka yang merokok memiliki risiko terkena kanker paru 7,8 kali lebih besar dibandingkan mereka yang tidak merokok (Kemenkes RI, 2013). Merokok juga meningkatkan risiko terjadinya impotensi sampai dengan 50\% (Kemenkes RI, 2013). Selain itu, merokok juga menimbulkan beban ekonomi yang tidak kecil. Beban ekonomi akibat merokok ini, lebih banyak dialami oleh masyarakat rumah tangga miskin, karena pengeluaran untuk rokok pada rumah tangga miskin di Indonesia jauh lebih tinggi dibandingkan dengan pengeluaran utama lainnya, seperti pembelian telur, susu, daging, biaya pendidikan maupun biaya kesehatan. Sebuah studi menyebutkan bahwa pengeluaran rumah tangga miskin di Indonesia untuk rokok adalah lima kali lebih tinggi daripada pengeluaran untuk telur dan susu; 6,5 kali lebih tinggi dibandingkan untuk biaya kesehatan, dan 9 kali lebih tinggi dibandingkan untuk pembelian daging (Kemenkes RI, 2013). Konsekuensi lain dari merokok adalah merokok merupakan pintu masuk terjadinya perilaku penyalahgunaan narkoba, utamanya jenis ganja (Astuti, 2016; Lai, Lai, Page, \& McCoy, 2000). Terkait dengan hal ini, penelitian yang menganalis data survei narkoba pada pelajar di Indonesia menunjukkan bahwa median lama waktu dari mulai merokok sampai menyalahgunakan ganja adalah dua tahun (Astuti, 2013).
Menurut sebuah penelitian, periode yang paling kritis untuk inisiasi merokok di kalangan anak laki-laki di Indonesia adalah di awal dan pertengahan masa remaja $(\mathrm{Ng}$, Weinehall, \& Öhman, 2007). Fakta tersebut dibuktikan oleh data Susenas tahun 1995, 2001, dan 2004 serta Riskesdas 2007 dan 2010 yang menunjukkan bahwa mayoritas perokok di Indonesia memulai dari usia muda, yaitu hampir $80 \%$ pada usia sebelum 19 tahun (Kemenkes RI, 2013). Data itu dipertegas dengan survei nasional perkembangan penyalahgunaan dan peredaran gelap narkoba pada kelompok pelajar/mahasiswa di Indonesia tahun 2011 yang menunjukkkan bahwa dari 708 pelajar/mahasiswa yang merokok mendahului penyalahgunaan ganja, $60 \%$ memulai merokok pada usia 10 - 14 tahun (Astuti, 2013). Di antara risiko yang akan dialami pada perokok usia muda, berdasarkan fakta yang banyak terjadi adalah perilaku merokok tersebut akan berkelanjutan hingga dewasa (Oshi et al., 2018).

Banyak faktor risiko dan protektif yang memiliki pengaruh dalam perilaku merokok remaja laki-laki, yaitu kondisi intrapersonal dan interpersonal remaja, sosial, budaya, dan karakteristik lingkungan (Guo et al., 2007; Piko, Luszczynska, Gibbons, \& Teközel, 2005)434 middle and high school students $(48.6 \%$ boys, $51.4 \%$ girls. Faktor intra personal adalah niat dan keinginan menjadi seorang laki-laki yang sebenarnya serta memiliki sikap positif terhadap perilaku merokok. Sedangkan faktor interpersonal adalah orangtua yang merokok, guru yang merokok, dan pengaruh teman sebaya (norma subyektif) (Ng et al., 2007). Literatur lain menyebutkan bahwa pencapaian akademik, kepuasan hidup, dan orientasi pada masa depan adalah faktor sosial yang mempengaruhi remaja laki-laki merokok (Piko et al., 2005) life satisfaction and future-orientedness. Pencapaian akademik, menurut penelitian tersebut merupakan faktor yang signifikan mempengaruhi remaja merokok. Pencapaian akademik yang tinggi berhubungan dengan pemilihan teman sebaya. Mereka yang memiliki pencapaian akademik yang baik cenderung lebih terlindungi dari perilaku merokok karena mereka melakukan seleksi terhadap teman sebayanya. Dalam penyataan lain, remaja laki-laki yang merokok tidak hanya cenderung mendapatkan 
prestasi akademik yang rendah, akan tetapi juga cenderung memilih teman yang juga perokok dan memiliki pencapaian akademik yang rendah. Kondisi itu pada akhirnya memperkuat perilaku merokok yang mereka lakukan (Piko et al., 2005) life satisfaction and future-orientedness.

Meskipun faktor-faktor risiko perilaku merokok di kalangan remaja di Indonesia sudah banyak diteliti dalam berbagai survei, namun pengetahuan secara mendalam mengenai peranan niat, norma subyektif, dan lingkungan sosial masih belum banyak diteliti. Padahal, pendekatan kualitatif diperlukan untuk membantu praktisi promotor pendidik kesehatan maupun pengelola program untuk merancang program pencegahan merokok pada remaja yang lebih efektif dan mengakomodir kondisi sosial di kalangan remaja. Dengan demikian, penelitian ini bertujuan untuk mengetahui informasi yang mendalam tentang gambaran faktor-faktor yang mendukung dan menghambat terjadinya perilaku merokok di kalangan remaja laki-laki siswa SMP Swasta X di Kota Depok.

\section{SUBYEK DAN METODE}

Penelitian ini merupakan penelitian kualitatif dengan rancangan Rapid Assesment Procedure (RAP), yaitu penelitian yang dapat dilakukan dalam waktu singkat untuk memahami lebih dalam terkait perilaku merokok pada remaja laki-laki siswa SMP Swasta di Kota Depok. Adapun informasi yang ingin digali adalah terkait norma subyektif, niat, dan lingkungan sosial yang berhubungan dengan perilaku merokok remaja laki-laki. Penelitian ini menggunakan data primer. Adapun tempat penelitian adalah sekolah tingkat Pertama (SMP) $\mathrm{X}$ di wilayah Kecamatan Pancoran Mas Kota Depok, Jawa Barat. Sekolah tersebut dipilih karena informasi dari guru di sekolah tersebut, cukup banyak siswa diketahui berperilaku merokok. Sedangkan waktu penelitian dilakukan pada bulan November - Desember 2018.

Pengumpulan data penelitian akan menggunakan teknik Wawancara Mendalam (WM). Sampel dalam penelitian ini ditentukan dengan metode purposive sampling, yaitu pengambilan sampel secara sengaja dengan mempertimbangkan syarat-syarat adequacy, appropriateness, dan tidak ada informasi baru (saturasi). Informan dalam penelitian ini adalah siswa-siswa laki-laki baik perokok yang berasal dari SMP Swasta X yang terletak di Kecamatan Pancoran Mas Kota Depok. Selain itu, dalam penelitian ini juga melibatkan informan kunci, yaitu guru sekolah tersebut. Pemilihan sampel dilakukan dengan bantuan guru sekolah yang memahami perilaku merokok siswa pria di sekolah tersebut. Sebelum dilakukan diwawancara, informan diberikan penjelasan terlebih dahulu terkait kesukarelaan terlibat dalam penelitian ini dan kerahasiaan informasi. Setelah informan memahami hal tersebut, kemudian informan menanda tangani lembar persetujuan sebagai tanda setuju terlibat sebagai informan penelitian.

\section{HASIL}

SMP Swasta X adalah sekolah yang tidak dikenakan pungutan biaya. Sekolah ini dikelola oleh Yayasan Bina Insan Mandiri (YABIM), Nama SMP ini tidak terlepas dari sejarah sekolah ini yang pada awal pendiriannya dimulai dari sudut masjid di terminal. Sekolah ini memiliki siswa lebih dari 3000 orang siswa. Untuk operasional, sekolah ini mengandalkan bantuan dari lembaga-lembaga peduli pendidikan, partiasipasi masyarakat, pemerintah, dan unit usaha mandiri yang dimiliki yayasan (Thamrin, 2016).

Berdasarkan cerita dari Mtm, informan kunci penelitian ini, awalnya sekolah ini memang dikhususkan untuk anak-anak jalanan. Anak-anak tersebut mencari uang dengan mengamen, namun tetap kembali untuk sekolah. Untuk kalangan keluarga tertentu, alasan menyekolahkan anaknya di sekolah ini adalah karena kapasitas sekolah negeri di Kota Depok terbatas dan memerlukan uang yang tidak sedikit jika mendaftarkan ke sekolah swasta, maka sekolah ini menjadi pilihan mereka dan karena alasan membantu warga, sekolah ini pun menerima anak-anak dari keluarga dhuafa dan dari keluarga yang terpisah ayah ibunya karena perceraian. Walaupun sekolah ini adalah sekolah tak berbayar tetapi sekolah ini cukup dapat diandalkan prestasinya. Di antaranya, pernah menjadi Pusat Kegiatan Belajar Masyarakat (PKBM) se Jawa Barat dan mendapatkan penghargaan dari Gubernur Jawa Barat, Ahmad Heryawan di tahun 2012 (Thamrin, 2016). 
Tabel 1. Identitas Informan

\begin{tabular}{lccl}
\hline \multicolumn{1}{c}{ Nama Inisial Informan } & Usia (thn) & Usia Mulai Merokok (th) & Frekuensi Merokok \\
\hline Khl & 16 & 10 & 12 batang/hari \\
By S & 17 & 10 & 12 batang/hari \\
Rrdn Vn & 14 & 13 & $3-4$ batang/minggu \\
Adrn Wjy & 15 & 12 & 12 batang/hari \\
Fdr & 16 & 15 & 5 batang/hari \\
Ahd & 15 & 13 & 3 batang/minggu \\
A. Drmwn & 17 & 16 & 1 batang/hari \\
Vk Zksh & 18 & 14 & $1-2$ batang/minggu \\
M.Rf & 13 & 13 & 2 batang/hari \\
M. Rm & 17 & 11 & 1 batang/hari \\
Mtsn (Informan Kunci) & 36 & 12 & Sudah lama berhenti \\
\hline
\end{tabular}

\section{Perilaku Remaja Merokok}

Informan penelitian ini memulai merokok pada usia antara $10-16$ tahun. Frekuensi merokoknya bervariasi, paling sedikit antara 1 4 batang/minggu dan paling banyak 1 bungkus rokok perhari atau 12 batang sehari.

"Mulai merokok usia 10 tahun, sehari tiga batang... Tapi kalau diingat-ingat sebungkus sehari, jadi 12 batang.." (Vk Zksh, 18 th)

"Saya mulai merokok sejak umur 11 tahun, sekarang umur saya 17 tahun, jadi sudah 6 tahun saya merokok...” (Rmdn, 17 th)

\section{Norma Subyektif Remaja tentang Merokok Awal Merokok dan Alasan Menerima Rokok}

Para informan dikenalkan oleh teman yang telah merokok ketika kumpul-kumpul (nongkrong) di tempat berkumpulnya anakanak sekolah tersebut. Tidak ada informan yang mengatakan merokok atas inisiatif sendiri. Seluruhnya menerangkan memulai kebiasaan merokok dari dorongan, paksaan, atau rayuan teman-teman.

"Ya gitu...jadi nih lagi nongkrong doang, dari temen-temen pergaulan di kampong Lio, ..trus iseng nyoba-nyoba ditawarin rokok sama temen terus, lama-lama eh ketagihan, trus saya sempet berhenti, eh kena lagi pas lagi nongkrong-nongkrong, tapi sekarang udah agak berkurang. Kan hargai temen yak waktu itu, temen sampe bilang gini "lu ga hargain gw parah banget lu. Yang penting diisep dlu dah sebatang dua batang, buat hargain temen dulu. Takut dibilang alay sama temen-temen kalau ga ngerokok, kalau ditolak dibilang "ah lebay lu ga ngerokok...” (Informan Vk Zksh, 18 th).

“...Awalnya sih pas ketemu temen di Jakarta. Kata teman saya ikut yuk, kemana? Ya saya ikut, pas masih ada kereta ekonomi, saya ikut, nggak lama lagi, pas saya ke sini maksudnya merantau ke sini, dari Jakarta ke sinj. Terus saya diajakin nyapu... nyapu di kereta, eee... kemudian turun di sini, terus saya ikut aja sekolah di sini, sekolah di sini ya pas pulang ngamennya nih beli rokok patungan ini duitnya, nih beli rokok, ada yang jalan, terus saya yang jalan aja. Ya tadinya saya juga mau nolak, kalau tar saya menolak yang ada tar nggak enak. Nggak ngehargai..." (Informan By, 17 th).

Informan yang memulai kebiasaan merokok dari mencoba rokok yang ditawari teman mengemukakan bahwa awalnya merasakan rokok karena ditawari teman. Ketika ditawarkan oleh teman, sangat tidak enak jika tawaran tersebut ditolak, apalagi dengan alasan tidak baik untuk kesehatan. Awalnya menerima tawaran karena bagi yang tidak mau menerima tawaran akan dituduh sebagai orang yang lebay, atau dicap tidak menghargai teman yang menawarkan. Bahkan ada yang bercerita kalau ada tawaran patungan uang untuk membeli rokok, sehingga ketika ditawari rokok yang dibeli secara patungan tersebut, ada rasa ikut membeli dan nggak enak kalau tidak ikut mengisap rokok.

"Awalnya dari karena deket-deket teman. Pas maen warnet, sekitaran dua tahun 
yang lalu. Kan lagi maen, trus itu bocahbocah pada patungan, sekitar 6 orang, dari temen deket rumah. Trus pas patungan, saya bilang enga ngerokok, teman saya bilang, yah enga enak lah, sudah patungan, tapi enga ngerokok. Padahal saya kira awalnya patungan itu buat beli es. Teman bilang, yah enga enak lah, sudah patungan, sudah deh isep aja. Jadinya saya isep aja, (kalau menolak) merasa enga enak sama teman, karena sudah patungan...." (Informan Adrn Wjy, 15 th).

"Waktu itu saya umur 11 tahun, saya sedang main sama teman, kemudian diajak teman, ditawarin rokok, pertama-tama saya batuk ek ek, lama lama jadi biasa. Ditawarin teman, awalnya nolak tapi dipaksa, cobacoba kagak enak nolak, katanya kagak ditemenin..." (Rmdn, 17 th).

\section{Bahaya Merokok}

Seluruh informan mengatakan rokok berbahaya untuk kesehatan. Ada yang berpendapat rokok hanya buang-buang uang dan waktu, namun tidak dapat menjelaskan secara detil bahaya yang dimaksud. Beberapa mengemukakan bahaya yang tercantum di kemasan rokok, tanpa merinci mekanisme timbulnya penyakit itu pada perokok.

Sakit kanker, bibir rusak, jantung jadi hitam, tenggorokan bolong, kanker lidah, kanker bibir, hipertensi, wanita gak bisa hamil. Katanya jantung, jantung gua kalau saya lihatin bungkus rokok, ada tulisan "rokok mетьипинти...” (Informan Rmdn, ... th)

"Ga tau, ga pernah denger. Biasa cuma dikasih doank. Cuma saya kan nih pas lagi main lagu-lagu (ngeband), pas ngerasain rokok nih lama-lama jadi cepet capek, ngosngosan kalau ngerokok. Pas main bola juga gitu. Kalau temen-temen juga ga tau, itu mah urusan masing-masing." (Informan Vk Zksh, 18 th)

Walaupun seluruh informan mengetahui bahaya merokok, akan tetapi mereka tetap merokok. Sebagian mengatakan, walaupun mengetahui bahaya rokok tetapi lebih mempercayai perkataan teman yang berpendapat bahwa bahaya rokok yang ada di bungkus rokok hanya bohongan saja. Sedangkan sebagian yang mengatakan bahwa bahaya rokok tidak pernah menjadi pembicaraan dengan teman sesame perokok sehingga bahaya rokok tidak menjadi perhatian bagi mereka.

"Bahaya, Berbahaya sih. Berbahaya, tidak bagus buat kesehatan tubuh, cuma bingung juga ngisap atau nggak. Bisa punya penyakit. Tapi teman-teman bilang itu itu cuma bohongan, cuma buat nakut-nakutin aja, supaya kamu nggak merokok. Sebenarnya pengen banget berhenti...." (Khl, 18 th)

"Ya itu, bisa paru-paru basah terus merusak tenggorokan.Teman-teman ya ga pernah bilang gitu. Ga pernah bicarain bahaya merokok, tapi tau. Ya ga tau juga mereka taunya dari mana..." (Fdr, 16 th)

\section{Persepsi Manfaat Merokok}

Terdapat dua pendapat berbeda diantara informan. Sebagian besar informan mengatakan bahwa merokok tidak ada manfaatnya, sementara itu, ada informan lainnya mengatakan bahwa merokok dapat menghilangkan pusing, rasa asem di mulut terutama setelah makan, dan rasa tenang setelah mengisap rokok. Walaupun informan mengetahui merokok tidak ada manfaatnya, akan tetapi ketika melihat teman merokok, jadi terpengaruh untuk merokok, apalagi jika habis makan

"Ga ada manfaatnya sih........ Cuma kalau lihat orang merokok.......... gimana ya, habis makan tuh enak ....kalau merokok...." (Informan Khl, 187 th)

"Kalau buat saya sendiri, ....ada. Kalau saya abis makan,............mulut ini terasa asem gitu, asal ngerokok ngilangin asem...." (Informan Adrn Wjy, 15 th)

\section{Keinginan untuk Berhenti Merokok}

Diantara informan yang ditemui peneliti, terdapat informan yang menceritakan permah berpikir untuk berhenti merokok, namun ada pula yang tidak pernah. Informan yang pernah berpikir dan berusaha untuk berhenti merokok menceritakan upaya yang pernah dilakukan yaitu pindah ke kota lain agar terpisah dari teman-teman yang merokok. Ada pula yang berpikir untuk 
menjaga kesehatan atau menghindari agar tidak kecanduan, sehingga pernah berusaha berhenti merokok. Namun informan lain mengutarakan belum pernah berpikir untuk berhenti merokok, melainkan menunggu perkembangan nanti. Informan yang pernah berusaha berhenti merokok, tidak bertahan lama, kembali merokok ketika bertemu teman yang merokok dan ditawari rokok.

"Pernah ingin berhenti merokok, tapi susah....Ya gitu, kalau lagi nongkrong sama temen, kena-kena juga ujungnya....Paling nanti bener-bener berhenti merokok kalau udah pengen gawe (kerja,red), kalau masih nongkrong-nongkrong mah susah, ditawarin mulu kalau main di tongkrongan....." (Informan A.Drmwn, 17th).

"Pernah...sekarang udah jarang merokok... kalau merokok sayang duit, jadi kasihan orang tua yang ngasih duit kalau buat beli rokok". (Informan Vk Zksh, 18 th).

\section{Anggapan tentang Teman yang tidak merokok}

Walaupun informan yang ditemui oleh pewawancara adalah remaja yang telah menjadi perokok aktif, namun sebagian dari mereka berpendapat bahwa teman yang tidak merokok itu baik, perlu ditiru, dan keren. Menjadi remaja yang tidak merokok sangat baik menurut informan yang merokok tersebut. Selanjutnya, informan menggambarkan bahwa aktivitas teman2 yang merokok dan tidak merokok berbeda. Kelompok yang merokok, menurut informan lebih banyak aktivitas kumpul-kumpul atau nongkrongnongkrong, sedangkan yang tidak merokok umumnya tinggal dirumah, atau kalaupun ikut nongkrong hanya sebentar.

"Bagus, mangkanya saya pengen banget ngerasain jadi orang yang tidak merokok... saya bingung juga ada sebagian yang merokok, ada yang tidak merokok..." (Informan Khl, 18 th)

"Teman saya ada yang merokok, ada juga yang tidak merokok. Teman-teman yang merokok sering nongkrong-nongkrong, sedangkan yang tidak merokok lebih banyak tinggal di rumah..." (Informan, Ahd, 13th).

\section{Upaya Menawarkan rokok ke teman}

Sebagaimana uraian yang disampaikan oleh informan tentang awal mulai merokok yang sebagian besar didapat dari tawaran teman, maka umumnya informan yang merokok juga pernah menawarkan rokok kepada teman lain. Beberapa informan mengatakan tidak pernah menawarkan rokok pada teman lainnya. Alasan yang dikemukakan informan terkait informasi tentang menawarkan rokok ke teman adalah karena pertemanan, kebiasaan dalam pergaulan, dan bentuk keramahtamahan. Dilihat dari respon penerima tawaran, dikemukakan informan, ada yang menerima, ada pula yang menolak.

"Kan saya belum tahu waktu itu. Kata temen saya, saya enggak ngerokok yan. Ya sudah. (Itu) temen di rumah. (Jadi) baru pertamatama temen itu maen ke rumah, saya kan ada rokok nih, saya tawarin rokok, tapi dia bilang enga ngerokok. Saya ambil aer aja. Abis itu, saya tahu dia enggak ngerokok. Dia bilang enggak ngerokok.." (Informan Adrn Wjy, 15 th)

"Pernah nawarin rokok, alasannya ya dia ngerokok nih dan lagi gak ngerokok jadi saya tawarin. Ya kan biasanya ngerokok bareng-bareng nah dia nggak bawa atau nggak punya rokok gitu jadi dikasih rokok jadi gitu suka gantian ngasih gitu. Dia cuma bilang isep ya..." (Informan Fdr, 16 th)

"Ga pernah (nawarin rokok). Saya malah yang ditawarin rokok, sayang duit kalau buat beli rokok mending buat nabung sama ongkos pulang. Sekarang juga lagi sering ngeband...." (Informan Vk Zksh, 18 th)

\section{Niat untuk Merokok \\ Uang untuk membeli rokok}

Sebagian besar informan perokok memperoleh uang untuk merokok dari bekerja seperti mengamen, jasa parkir, ojek payung, dan lainnya. Ada pula informan yang mendapatkan rokok dari pemberian teman. Hanya sedikit informan yang membeli rokok dari uang jajan yang diberikan orang tua.

Uang yang digunakan untuk membeli rokok hanya sebagian dari uang yang diperoleh informan dari hasil kerja kerasnya sebagai pengamen, juru parkir, ojek payung, atau lainnya. 
Sisa uang yang dihasilkan digunakan untuk membiayai pendidikan dan membantu orang tua. Ada pula informan yang mengemukakan bahwa uang yang diperoleh dari pekerjaan sebagaimana disebutkan sebelumnya, ada yang ditabung, walaupun hanya sebagian kecil dari uang yang diperoleh.

"Dari markir disono. Ga tiap hari juga jarang-jarang ini. Tergantung sedapetnya aja 50 ribu kalau lagi rame, bisa juga 20 ribu. Paling 5 ribu buat beli rokok sisanya buat yang lain, buat jajan. Pernah kepikiran buat ditabung. Cuma kalau udah ketemu temen mah susah. Mentok-mentok dari yang 5 ribu tadi, bisa 2 ribu buat ditabung...." (Informan A.Drmwn, . 17 th)

"Untuk beli rokok dari saya ngojek payung dan ngamen, kadang dikasih teman. Dari Uang parkir dapat 100 ribu, uang ngamen dapat 50 ribu. saya beli rokokfilter harganya 18 ribu. Sisanya uang ditabung, beli baju, kan anak muda identik sama sweater..." (Informan Rmdn, 17 th).

"Dari ibu, uang jajan. Sebelumnya kerja di warkop, sekarang enga lagi. Dapat 1 juta per bulan. Uang juga buat jajan. Uang dari kerja, dikasi ke ibu 500 ribu atau 400 ribu atau 300 ribu, sisanya buat beli baju, jajan, rokok, dll. Rokoknya juga jadi sering. Belum. Enga bisa nabung kalau seribu-seribu gitu, enga kepikiran bisa gede gitu..." (Informan Adrn Wjy, 15 th)

\section{Kegiatan yang dilakukan untuk membeli rokok jika tidak memiliki uang}

Informan menyampaikan bahwa selalu memiliki uang untuk membeli rokok yang diperoleh dari hasil mengamen, jasa parkir, ojek payung, dan lainnya. Jika sedang tidak memiliki uang, maka informan akan meminta rokok pada teman yang memiliki rokok. Tidak jarang juga ada kondisi tidak memiliki uang untuk membeli rokok dan tidak ada yang dapat diminta, maka mereka memilih tidak merokok. Sebagian remaja merokok mengatakan selalu memiliki uang jika ingin merokok.
“... Ya kan gantian biasanya temen gak punya duit saya yang beli rokok kalau saya gak punya duit temen yang beli rokok..." (Informan Fdr, 16 th)

“... ya ga usah kalau lagi ga punya duit. Biarin bae”. (Informan A.Drmwn, 17 th).

"Kagak pernah. Alhamdulillah selalu ada. Ada kejadian, pengen ngerokok, tapi enga punya rokok, kalau sudah malam, pengen beli ke warung dekat rumah tapi sudah pada tutup. Kalau sama temen, jadi pergi keluar sama temen, jalan cari warung, naek motor, cari warung untuk beli rokok..." (Informan Adrn Wjy, 15 th)

\section{Lingkungan Sosial yang Mempengaruhi Perilaku Merokok Guru atau keluarga yang merokok}

Sebagian informan ada yang pernah melihat guru merokok di depan siswa. Namun sebagian siswa yang lain tidak pernah melihat guru merokok walaupun sebenarnya juga perokok. Namun guru yang terlihat dan tidak terlihat merokok didepan murid, tidak menawarkan rokok pada muruid. Pernah ada guru yang menawarkan rokok ke murid, tapi jumlahnya sedikit dan sangat terbatas. Adapun mengenai anggota keluarga, ada informan yang memiliki orang tua perokok (ayah), dan sering merokok didepan anak-anaknya. Salah satu informan menceritakan pernah mengingatkan orangtuanya untuk tidak merokok, namun tidak dihiraukan.

“..........Kalau guru ga pernah nawarin. Bapak juga ga pernah. Abang malah bilang lu jangan ikutin gue ngerokok..." (Informan Vk Zksh 18 th)

".sama bapak sering, kadang ditawarin, kadang ambil sendiri. Kalau sama kakak mah sering, kadang juga kalau enga punya rokok, kita jalan sendiri keluar cari rokok.." (Informan Adrn Wjy, 15 th)

"Saya memiliki ayah yang hidup terpisah dengan ibu. Ayah saya merokok, sering merokok didepan saya. Pernah saya mengingatkan untuk tidak merokok, tapi hanya didiamkan saja. Saya tidak pernah mengingatkan bahaya merokok ke ayah, 
biar dia tau sendiri. Tanggapan ayah ketika saya minta berhenti merokok biasa saja..." (Informan Ahd, 13 th)

"Pernah ditawarin sama guru silat, tapi saya tolak. Kata guru silat kalau tidak merokok, mulut asam, pahit. Kalau bapak dan abang ngak pernah nawarin rokok.." (Informan Rmdn, 17 th)

\section{Iklan Rokok di Media}

Seluruh informan mengetahui iklan rokok, baik di media audiovosual seperti televisi, maupun media lain. Pendapat sebagian informan membenarkan peringatan di iklan dan kemasan rokok, namun sebagian lain berpendapat itu hanya iklan dan melebih-lebihkan saja. Tentang peringatan di kemasan rokok, sebagian informan merasa takut, sementara sebagian lain tidak merasa itu sebagai ancaman sehingga tidak perlu ditakuti. Ada satu informan yang tidak paham maksud di iklan rokok.

“.....TV, HP, koran, media sosial. Saya takut kalau jantungnya bolong, dari bungkus rokok tertulis Rokok akan membunuhmu..." ( Informan Rmdn, 17 th).

“....Ya kadang-kadang aahhh... Ini boong kata keluarga saya juga cuma editan..." (Informan Bayu, ....th)

“...sama waktu itu pas lagi di warung, ngeliat iklannya ga selesai dan ga paham juga maksudnya apa...." (Informan Vk Zksh 18 th)

\section{Edukasi Bahaya Merokok}

Sebagian besar informan pernah mengikuti Edukasi bahaya merokok, hanya sebagaian kecil informan yang tidak pernah mendengar bahaya merokok. Adapun informan yang pernah mengikutinya, edukasi dilakukan oleh berbagai sumber. Ada yang berasal dari ayah, ibu, guru, kakek, kakak, , atau mahasiswa yang berkunjung ke lokasi sekolah informan dan praktek melakukan penyuluhan. Isi edukasi yang pernah diterima adalah tentang bahaya rokok terhadap kesehatan,

"Di sekolah ga ada yang ngasih tau, kalau di rumah pernah dibilang jangan ngerokok sama bapak, tetapi ga pernah dikasih tau bahayanya. Dari kakak, jangan ngerokok, jangan kayak gw lu, biar gw aja yang bandel, tapi ga pernah dikasih tau bahayanya, ga pernah nanya juga, iya-iyain aja.." (Informan Vk Zksh 18 th).

"Guru pernah ngasih tau bahaya ngerokok. Jangan kebanyakan ngerokok (walapun ga spesifik). Kalau orang tua bilang jangan ngerokok juga, kalau udah kecanduan udah susah. Orang tua ga tau kalau anaknya ngerokok..." (Informan A.Drmwn, 17th).

"Belum pernah dengar (tentang penyuluhan tentang bahaya rokok)....." (Informan Khl, 18 th)

\section{DISKUSI}

Penelitian tentang perilaku merokok di kalangan remaja laki-laki guna mengeksplorasi faktor perilaku merokok dan faktor-faktor yang mendukungnya telah dilakukan pada siswa lakilaki SMP Swasta X di Kota Depok, Jawa Barat. Metode wawancara mendalam yang dilakukan pada informan yang mewakili kelompok remaja laki-laki yang merokok dan guru telah memberikan gambaran tentang karakteristik perilaku merokok di kalangan remaja tersebut, norma subjektif, niat untuk merokok, dan lingkungan sosial yang dianggap berperan pada perilaku merokok mereka.

Perilaku merokok remaja pada penelitian ini dapat dilihat dari usia pertama merokok, jumlah batang rokok yang dihisap perhari, serta cara memperoleh rokok. Pajanan terhadap rokok pada kelompok remaja di penelitian ini dimulai sejak usia 10-16 tahun yang diawali dengan tawaran dari teman-teman sebaya. Tidak ada yang mengatakan belajar merokok dari iklan (Prabandari \& Dewi, 2016) atau meniru orang tua (Bird, Staines-orozco, \& Moraros, 2016) Merujuk penelitian sebelumnya, di sebagian masyarakat Indonesia, kebiasaan merokok pada remaja laki-laki di Indonesia dimulai pada usia 10 - 12 tahun ketika mereka diperkenalkan dengan rokok saat upacara sunatan (khitanan) yang merupakan upacara tradisional keagamaan (Ng et al., 2007). Pada upacara tersebut, rokok juga diberikan kepada tamu, yang umumnya adalah remaja laki-laki dan teman-teman dari remaja laki-laki yang disunat atau dikhitan $(\mathrm{Ng}$ et al., 2007). 
Dilihat dari jumlah konsumsi rokok, penelitian ini mendapatkan bahwa konsumsi merokok remaja laki-laki diketahui sekurangnya satu batang per hari, paling banyak satu bungkus perhari, biasanya $4-12$ tahun batang rerata per hari. Umumnya mereka membeli sendiri rokok tersebut dengan uang yang diperoleh dari usaha sendiri, misalnya dengan mengamen. Jika tidak ada uang, dan tidak ada teman yang memberi, mereka mengatakan tidak merokok pada hari itu. Ada informan yang merasa bersalah jika menggunakan uang dari orang tua untuk membeli rokok. Penelitian sebelumnya memang menunjukkan adanya remaja yang takut ketahuan merokok oleh orang tua ( $\mathrm{Ng}$ et al., 2007). Namun pada penelitian ini gambarannya berbeda, pendapat yang dikemukakan bukan takut, tetapi ada rasa tidak nyaman jika diketahui oleh orangtuanya melakukan perilaku merokok.

Gambaran perilaku lain yang terungkap dalam penelitian ini adalah tidak adanya remaja laki-laki yang merokok di lingkungan rumah tempat tinggalnya. Aktivitas merokok umumnya dilakukan ketika berkumpul dengan teman-teman di luar rumah (atau dalam bahasa mereka adalah nongkrong). Hal itu sejalan dengan gambaran perilaku remaja pria merokok yang suka bercengkrama dengan teman-temannya di luar rumah. Kesempatan berkumpul dengan temanteman perokok memudahkan remaja lain untuk memulai merokok, karena mendapat tawaran untuk mulai mencoba rokok. Sebagaimana penelitian sebelumnya menyebutkan bahwa teman dekat yang merokok merupakan faktor risiko remaja untuk merokok (Chung \& Joung, 2014).

Perilaku merokok remaja laki-laki sangat dipengaruhi norma subjektif dalam bentuk halhal yang mendorong remaja merokok, niat untuk merokok yang digambarkan dengan alasan mereka merokok, serta hal-hal di lingkungan yang mendukung mereka untuk jadi perokok terutama contoh yang membuat mereka merasa tidak bersalah ketika merokok.

Persepsi remaja laki-laki yang merokok tentang rokok dalam penelitian ini tidak terlalu jelas. Penelitian ini menemukan bahwa hampir semua informan mengatakan tidak dapat menggambarkan tujuan mereka merokok. Di beberapa tempat di Indonesia, seperti di masyarakat Jawa, merokok telah dianggap sebagai budaya yang telah terinternalisasi dalam kebiasaan masyarakat (Ng et al., 2007). Kondisi itu menyebabkan remaja laki-laki beranggapan bahwa merokok adalah perilaku yang umum dan bukan hal yang tabu atau terlarang. Dalam berbagai kegiatan kemasyarakatan, seperti pertemuan warga atau pertunjukan wayang, laki-laki merokok adalah hal yang biasa $(\mathrm{Ng}$ et al., 2007). Pada budaya semacam itu telah menjadikan orang dengan mudah menerima jika remaja laki-laki merokok, karena merokok lazim dilakukan oleh kaum laki-laki, termasuk remaja

Dorongan remaja laki-laki perokok yang dikemukakan informan pada penelitian ini adalah rasa solidaritas antar teman, sehingga tidak nyaman menolak tawaran rokok dari teman. Informasi yang sama juga sejalan dengan penelitian sebelumnya bahwa faktor teman yang memberikan rokok dan ingin terlihat seperti lakilaki pada umumnya adalah pendorong utama remaja memulai kebiasan merokok ( $\mathrm{Ng}$ et al., 2007). Tidak ada informan yang mengemukakan inisiatif merokok datang dari dalam diri sendiri secara spontan. Identifikasi faktor pendorong ini sangat penting untuk merancang strategi mengatasi tingginya angka merokok pada remaja sebagaimana terlihat pada penelitian lain (Prabandari \& Dewi, 2016).

Seluruh remaja laki-laki perokok dalam penelitian ini mengemukakan bahwa merokok itu tidak ada manfaatnya, hanya membuang uang dan waktu, bahkan lebih jauh menurut mereka rokok tersebut berbahaya. Hal ini bertentangan dengan perilaku merokok yang ditunjukkan remaja yang menjadi informan dalam penelitian ini, yaitu menerima tawaran merokok dari teman atau hanya sekedar ingin terlihat hebat sebagai lakilaki. Menurut sebagian informan, bahaya rokok diantaranya menganggu kesehatan pernafasan, hati, dan jantung. Informasi itu didapatkan mereka dari iklan atau kemasan rokok. Konfirmasi tentang bahaya merokok dikemukakan oleh informan pada penelitian ini disampaikan dalam bentuk keluhan yang dirasakan ketika menghisap rokok, yaitu batuk-batuk atau sesak nafas. Informasi tentang bahaya merokok itu sesungguhnya, berdasarkan penelitian ini, menakutkan bagi remaja perokok. Akan tetapi, hal itu tidak mengurangi kebiasaan dan ketergantungan 
mereka terhadap rokok. Fenomena ini juga ditemukan pada penelitian terdahulu yang menunjukkan tingkat pengetahuan terhadap bahaya merokok tidak berbanding lurus dengan kesadaran untuk menjauhi rokok (Prabandari \& Dewi, 2016). Hasil penelitian sebelumnya juga memang menunjukkan bahwa pajanan terhadap gambar peringatan bahaya merokok terhadap kesehatan, baik dalam kemasan rokok maupun iklan rokok terhadap persepsi khalayak terkait aktivitas merokok (yaitu mulai dari merasakan rangsangan yang ada, memberikan makna tentang aktivitas merokok, sampai mempercayai aktivitas merokoknya) memiliki pengaruh yang lemah (Nugraha, 2015).

Norma lain yang menarik adalah perilaku memperkenalkan rokok kepada teman. Walaupun remaja perokok telah merasakan pengaruh rokok terhadap dirinya dan tidak melihat ada manfaat, namun mereka tetap tidak dapat menolak memberikan rokok pada teman lain. Tawaran kepada teman menurut mereka tidak secara aktif dilakukan, melainkan dengan cara pasif, yaitu memberikan rokok yang diminta oleh teman. Sikap ini sebenarnya menunjukkan bahwa remaja laki-laki yang diteliti memiliki kesadaran bahwa merokok itu tidak baik dan tidak bermanfaat, sehingga tidak baik untuk diberikan pada teman. Namun mereka tidak sungguh-sungguh memahami. Akibatnya, sikap tenggang rasa antar teman membuat mereka tidak menolak ketika ada teman yang meminta rokok. Hal yang sama juga terlihat dari dorongan mendapatkan rokok ketika tidak ada uang dan tidak ada teman yang memberikan rokok, tidak ada sesuatu hal yang membuat mereka melakukan hal apa saja untuk mendapatkannya. Kondisi tersebut dijelaskan dalam penelitian terdahulu yang menunjukkan bahwa remaja laki-laki sebenarnya tahu bahaya merokok, namun mereka tidak memahami secara akurat setiap risiko dari gangguan kesehatan akibat rokok, termasuk gangguan kesehatan sebagai perokok pasif ( $\mathrm{Ng}$ et al., 2007).

Disadarinya bahaya merokok pada informan penelitian ini dapat dilihat dari upaya yang dilakukan remaja informan untuk berhenti merokok yang dilakukan dengan mencoba tidak mengonsumsi rokok atau menghindari dari teman-teman yang merokok. Ada informan yang mengatakan cukup berhasil upaya mengurangi atau menghindari rokok dengan menjauh dari teman perokok, namun segera mulai kembali setelah bertemu dan bergaul kembali dengan teman-teman yang merokok. Terkait hal ini, penelitian terdahulu menyatakan bahwa pelajar yang memutuskan untuk berhenti merokok dilaporkan stress karena mereka kehilangan pertemanan, teman-temannya menghindarinya karena dia tidak merokok (Chung \& Joung, 2014). Tekanan seperti itu yang mungkin menyebabkan, remaja laki-laki yang sudah mencoba berhenti merokok, menjadi merokok kembali ketika bertemu teman-temannya.

Niat merokok pada remaja umumnya lebih banyak dipegaruhi oleh faktor eksternal Hal ini terjadi karena informan mengemukakan merokok bukan sesuatu yang direncanakan, tapi terjadi begitu saja setelah mendapatkan dari orang lain ( $\mathrm{Ng}$ et al., 2007). Dari hasil wawancara, mayoritas informan tidak secara khusus memiliki niatan untuk membeli rokok melalui uang mereka sendiri, melainkan ditawarkan oleh teman khususnya pada saat pertama kali mereka merokok. Umumnya mereka merokok bila ada yang menawarkan, sedangkan jika tidak ada yang menawarkan, mereka tidak berusaha secara khusus untuk membeli rokok. Kondisi tersebut dijelaskan oleh penelitian terdahulu yang menunjukkan bahwa teman-teman yang merokok mempengaruhi niat remaja untuk merokok (Nagarkar \& Gadhave, 2015).

Gambaran ini menunjukkan, kekuatan dorongan internal bukanlah menjadi faktor dominan, tetapi lebih lebih disebabkan pada pengaruh teman dan kelompok. Hal ini perlu menjadi catatan, apabila kita ingin menurunkan angka perokok pada remaja, maka upaya yang penting dilakukan adalah memperkuat persepsi tentang manfaat dan bahaya merokok, serta menciptakan lingkungan rumah dan sekolah yang kondusif yang dapat mendukung upaya tersebut. Penelitian sebelumnya menunjukkan bahwa program pencegahan merokok berbasis sekolah sukses meningkatkan pengetahuan siswa tentang bahaya merokok dan membentuk sikap anti rokok pada siswa tersebut (Tahlil, Teuku, et al, 2013).

Lingkungan sosial memiliki pengaruh kuat untuk mendorong kebiasaan merokok pada remaja laki-laki, hal ini sejalan dengan penelitian- 
penelitian lain yang sebelumnya (Ng et al., 2007; Prabandari \& Dewi, 2016; Tahlil, Teuku. et al., 2013). Figur guru di sekolah dan orangtua di rumah secara tidak langsung turut mempengaruhi kebiasaan merokok remaja. Guru dan orangtua yang merokok mempengaruhi remaja untuk merokok pula (Al-Zalabani \& Kasim, 2015). Beberapa informan perokok menyampaikan kalau yang bersangkutan memiliki orang tua yang masih perokok, bahkan ada yang merokok secara terbuka di rumah, termasuk di depan anak-anak. Walaupun keberadaan orang tua yang merokok termasuk yang merokok di depan anakanak bukan pendorong utama sebagai pendorong kebiasaan merokok remaja perokok (Al-Zalabani \& Kasim, 2015), namun sikap permisif dan tidak melarang anak-anak dan remaja merokok, pada akhirnya meningkatkan jumlah perokok remaja. Tidak ditegur atau dilarang, mungkin dianggap sebagai sikap membiarkan, sehingga rasa bersalah remaja yang merokok tidak terlihat jelas. Kondisi tersebut mungkin dipengaruhi oleh tingkat pendidikan orangtua. Penelitian sebelumnya menunjukkan bahwa orangtua berpendidikan tinggi memiliki korelasi negatif terhadap perilaku merokok remaja karena orangtua tersebut membangun nilai dan kepercayaan negatif pada diri remaja terhadap rokok (Al-Zalabani \& Kasim, 2015).

Faktor eksternal lain diduga terkait dengan tingkat merokok pada remaja adalah iklan rokok dan iklan bahaya rokok. Menurut mayoritas informan, iklan rokok yang memuat bahaya rokok membuat mereka cenderung menjadi lebih takut mengkonsumsi rokok dalam jumlah banyak karena ancaman seperti rokok dapat membunuh, menyebabkan kanker, serangan jantung, dan dampak mematikan lainnya. Penelitian lain memang menunjukkan bahwa faktor teman perokok adalah faktor yang mempengaruhi keinginan seseorang untuk merokok (Chung \& Joung, 2014)

Dari berbagai penelitian sebelumnya, edukasi juga merupakan salah satu faktor pendorong persepsi bahaya merokok pada remaja (Ng et al., 2007; T. et al., 2013). Dalam penelitian ini, sebagian informan mengatakan bahwa mereka telah menerima edukasi baik yang dilakukan di lingkungan sekolah, misalkan oleh guru, mahasiswa, atau unsur lain, maupun di lingkungan rumah misalkan oleh orang tua atau saudara. Walaupun demikian, kebanyakan informan mengatakan edukasi ini seringkali tidak spesifik menjelaskan akan bahaya merokok dan bagaimana upaya untuk mengurangi atau menghilangkan konsumsi merokok. Edukasi ini biasanya dilakukan tidak berkelanjutan sehingga mayoritas informan walaupun sudah mendapat edukasi, tetap mengkonsumsi rokok karena dorongan dari teman-teman sebayanya. Penelitian menunjukkan program berbasis sekolah yang menjelaskan tentang bahaya merokok dan memberikan keterampilan untuk mengatakan tidak pada rokok efektif memberikan dukungan bagi remaja untuk tidak merokok (Bate et al., 2009; Tahlil, Teuku. et al., 2013).

Studi ini memiliki keterbatasan dalam hal pemilihan sampel penelitian. Siswa pria yang menjadi sampel penelitian ini adalah mereka yang umumnya memiliki tingkat sosial ekonomi rendah, termasuk di antara adalah anak jalanan yang tinggal di rumah singgah. Untuk memperkecil bias akibat hal di atas, tim peneliti mencoba untuk lebih menggunakan bahasa sehari-hari mereka ketika bertanya sehingga mereka lebih memahami pertanyaan yang dimaksud oleh peneliti.

\section{KESIMPULAN}

Berdasarkan penelitian ini, kesimpulan yang diambil adalah faktor norma subyektif adalah faktor yang paling berpengaruh dalam membentuk perilaku remaja laki-laki untuk merokok. Sementara iklan rokok adalah faktor yang paling sedikit mempengaruhi remaja untuk merokok. Norma subyektif yang terbentuk dari teman sebaya mereka adalah merokok merupakan identitas remaja ketika bercengkrama dengan teman bermainnya. Bercengkrama tanpa rokok adalah hal yang tabu buat remaja, sehingga dorongan merokok berasal dari teman sebaya, bukan dari dorongan internal, diri sendiri. Penelitian ini juga mendapatkan bahwa uang untuk membeli rokok didapatkan dari hasil bekerja, seperti ngamen atau menjadi waiters. Tidak ada yang menggunakan uang dari orangtua untuk merokok karena merasa bersalah jika menggunakan uang tersebut. Terkait edukasi, penelitian ini menunjukkan bahwa edukasi yang membangun keterampilan hidup (life skill) 
remaja belum didapatkan oleh informan.

Sedangkan saran yang diajukan oleh tim peneliti adalah edukasi bahaya merokok kepada remaja sebaiknya tidak menggunakan pendekatan konvensional, yaitu hanya dengan penyuluhan saja. Selain itu, remaja sebaiknya mendapatkan edukasi tentang bahaya merokok dengan pendekatan membangun keterampilan hidup (life skill) agar remaja mampu mengatakan "Tidak" pada rokok dan tidak terpengaruh oleh tawaran teman. Untuk lebih luas memahami perilaku merokok remaja laki-laki, penelitian lanjut dengan melibatkan siswa laki-laki dari sekolah dengan tingkat sosial ekonomi yang lebih bervariasi perlu dilakukan.

\section{DAFTAR PUSTAKA}

Al-Zalabani, A., \& Kasim, K. (2015). Prevalence and predictors of adolescents' cigarette smoking in Madinah, Saudi Arabia: A school-based crosssectional study. BMC Public Health, 15(1), 1-7. https://doi.org/10.1186/s12889-015-1363-8

Astuti, N. H. (2013). Analisis Kesintasan Hubungan Frekuensi Merokok dengan Penyalahgunaan Ganja pada Pelajar/Mahasiswa Perokok di Indonesia Tahun 2011. Fakultas Kesehatan Masyarakat Universitas Indonesia.

Astuti, N. H. (2016). Merokok pintu masuk untuk penyalahgunaan narkoba jenis ganja. Arkesmas, $1(1)$.

Bate, S. L., Stigler, M. H., Thompson, M. S., Arora, M., Perry, C. L., Reddy, K. S., \& MacKinnon, D. P. (2009). Psychosocial mediators of a schoolbased tobacco prevention program in India: Results from the first year of project MYTRI. Prevention Science, 10(2), 116-128. https://doi. org/10.1007/s11121-008-0113-x

Bird, Y., Staines-orozco, H., \& Moraros, J. (2016). Adolescents ' smoking experiences , family structure, parental smoking and socio- economic status in Ciudad Juárez, Mexico. International Journal for Equity in Health, 1-9. https://doi. org/10.1186/s12939-016-0323-y

Chung, S. S., \& Joung, K. H. (2014). Risk Factors for Smoking Behaviors Among Adolescents. Journal of School Nursing, 30(4), 262-271. https://doi. org/10.1177/1059840513505222

Guo, Q., Johnson, C. A., Unger, J. B., Lee, L., Xie, B., Chou, C. P., ... Pentz, M. A. (2007). Utility of the theory of reasoned action and theory of planned behavior for predicting Chinese adolescent smoking. Addictive Behaviors, 32(5), 1066-1081. https://doi.org/10.1016/j.addbeh.2006.07.015
Kemenkes RI. (2013). Infodatin: Hari Tanpa Tembakau Sedunia.

Kementerian Kesehatan RI. (2018). Hasil Utama Riskesdas 2018.

Lai, S., Lai, H., Page, J. B., \& McCoy, C. B. (2000). The Association Between Cigarette Smoking and Drug Abuse in the United States. Journal of Addictive Diseases, 19(4), 11-24. https://doi. org/10.1300/J069v19n04_02

Nagarkar, A., \& Gadhave, S. (2015). Psychosocial Determinants of Intention to Use Tobacco Among Adolescents in India. Psychology, Community \& Health, 4(2), 65-74. https://doi.org/10.5964/pch. v4i2.106

$\mathrm{Ng}$, N., Weinehall, L., \& Öhman, A. (2007). 'If I don't smoke, I'm not a real man' - Indonesian teenage boys' views about smoking. Health Education Research, 22(6), 794-804. https://doi. org/10.1093/her/cyl104

Nugraha, A. W. (2015). PengaruhTerpaan Gambar Peringatan Kesehatan Terhadap Persepsi Khalayak Mengenai Aktivitas Merokok (Studi Pada Mahasiswa FISIP UI). In 2nd Indonesian Conference on Tobacco or Health. TCSC IAKMI.

Oshi, S. N., Oshi, D. C., Weaver, S., Agu, C. F., Smith, W., Roomes, T. R., ... Abel, D. (2018). A School-Based Study of the Influence of Students ' Relationship with Teachers on Their Cigarette Smoking Behaviour in Jamaican, 19, 7-12. https://doi.org/10.22034/APJCP.2018.19.S1.7

Piko, B. F., Luszczynska, A., Gibbons, F. X., \& Teközel, M. (2005). A culture-based study of personal and social influences of adolescent smoking. European Journal of Public Health, 15(4), 393-398. https://doi.org/10.1093/eurpub/ cki008

Prabandari, Y. S., \& Dewi, A. (2016). How do indonesian youth perceive cigarette advertising? A cross-sectional study among indonesian high school students. Global Health Action, 9(1). https://doi.org/10.3402/gha.v9.30914

Tahlil., T., et al. (2013). The impact of education programs on smoking prevention: a randomized controlled trial among 11 to 14 year olds in Aceh, Indonesia. BMC Public Health.

Thamrin, S. (2016). nur rohim pendiri sekolah-master jebol bendungan-airmatanya ketika ditanya asalusulnya. 